\title{
Goran Pavlić
}

\section{Od praktičkog do obrazovnog obrata: o proturječjima emancipatorske metodologije u izvedbenim studijima}

* Rad je dio istraživanja u sklopu znanstvenog projekta "Kako praksom vođeno teorijsko istraživanje u umjetničkoj izvedbi može doprinijeti hrvatskoj znanosti” (IP-2014-09-6963) koji podupire Hrvatska zaklada za znanost.

Kriza i kritike racionalnosti. Nasljeđe '68.

Ur. B. Mikulić/M. Žitko, Zagreb: Filozofski fakultet 2019. 


\section{SAŽETAK}

Od 1960-ih i tzv. praktičkog obrata u umjetničkom istraživanju razvija se specifični istraživački model prakse-kao-istraživanja i u domeni izvedbenih studija, koji se suprotstavlja klasičnom, "objektivističkom" pristupu tradicionalne teatrologije. Umjesto tretiranja izvedbenih umjetnosti kao djelatnosti koje rezultiraju dovršenim, zaokruženim umjetničkim djelima, koja se onda validiraju protokolima akademskih disciplina, praktički je obrat stavio naglasak na procesualnost, a ne na fiksiranost, aktivno sudjelovanje, a ne objektivnu distanciranost, autorefleksivnost a ne samosvijest (KERSHAW, 2011). Time je epistemološki legitimitet proširen s instance znanstvenice/znanstvenika i na nove subjekte u polju — izvedbene umjetnice/umjetnike, bez nužnih akademskih prerogativa. U posljednjih dvadesetak godina u umjetničkom je polju zamjetan tzv. obrazovni obrat, koji donekle baštini konceptualne i metodološke pretpostavke praktičkog, međutim u nekim suštinskim konzekvencama predstavlja i radikalan odmak od njih.

U kojoj su mjeri transformacije akademskog polja u okviru putanje "od praktičkog do obrazovnog obrata" demokratizirale pristup umjetnosti te restrukturirale samorazumijevanje dionika tog polja, pokušat ću izložiti polazeći od Rancièreove kritike Althussera i njegove teorije ideologije. Ako je u krajnjoj konzekvenci, kako tvrdi Rancière, čvrsta distinkcija znanosti i ideologije samo ojačala reakcionarnu politiku establishmenta, je li moguće analogno iznevjerenje emancipacijskih potencijala praktičkog obrata danas detektirati u obrazovnom obratu? 


\section{ABSTRACT}

Since the 1960 s and the practical turn in art research, a particular research model has emerged within the field of performance studies: practice-as-research. Its distinctive trait is a departure from the traditional, "objectivist" approach pursued by mainstream theatre studies. Instead of treating performing arts as activities that result in finalized, coherent artworks eventually evaluated and verified through protocols of established academic disciplines, the practical turn stressed the procedural aspects, and not the fixed nature of artworks, active participation, and not objective distance, self-reflexivity, and not self-consciousness (Kershaw, 2011). Thus, epistemological legitimacy was granted not only to scholars, but to new subjects in the field: performing artists, not necessarily academically trained. In the last 20 years a new turn is emerging in the field of art: the educational turn. It inherits some of the conceptual and methodological premises of the practical turn, yet departs significantly in some of its substantial outcomes.

Have the transformations of the academic field along the trajectory from the practical to the educational turn democratized, i.e. broadened the entrance to the field of art, and reshaped the selfunderstanding of artists and art theorists? I will try to answer these questions by starting from Rancière's critique of Althusser's theory of ideology. If, as Rancière claims, a strict distinction between science and ideology only corroborated the reactionary stance of the establishment, is it possible to detect an analogous betrayal of the practical turn's emancipatory potential by the educational turn? 
Dinamika dvadesetostoljetne humanistike bitno je obilježena nizom obrata, odnosno epistemoloških lomova koje su inaugurirali autori nekim svojim djelom ili pak više-manje paradigmatski koordiniranom skupinom ili školom. Zacijelo najpoznatiji takav paradigmatski lom predstavlja posthumno objavljeno de Saussureovo djelo Tečaj opće lingvistike iz 1916. koje je radikalno izmijenilo razumijevanje ontološkog statusa tekstova i svijeta na koji se tekstovi referiraju. Ta nova ontologija znaka impregnirala je velik broj disciplina u polju humanistike, napose lingvistiku, sociologiju, antropologiju te teoriju književnosti i nije ni previše odvažno niti ekscesno smatrati njezin nastup epohalnim.

Po širini donekle sličnog zahvata, ali puno manje simboličke snage i teorijske prodornosti, od 196o-ih nadalje pomalja se polako i izvedbeni obrat. Tako Erika Fischer-Lichte (2013) naglašava prevrednovanje prostorne situiranosti teatra koje se događa u tim godinama. Izvedbeni umjetnici nastoje raditi bilo gdje, samo ne u kazališnim zgradama. Posljedica je to zamora opresivnom normom akademski i kulturno ovjerenih prostora izvedbe - velikih, reprezentativnih zgrada, koje je buržoazija smatrala integralnim dijelom samog teatra - i želje za nadvladavanjem čvrstih granica između izvođača i publike koje je organizacija izvedbenih prostora dosljedno osnaživala. Taj prostorni pomak poetički je značajno doprinijeo reartikulaciji statusa režije, dramaturgije i glume, pa konzekventno reformirao i refleksiju o tome.

Riječ je o premještanju analitičke pažnje s objekata ili rezultata stvaralačkih ili poietičkih aktivnosti na izvedbu, procesualnost aktivnosti kojima se dolazi do tih rezultata, bili oni teorijski ili kritički tekstovi ili umjetnička djela. S obzirom na samu narav izvedbenih umjetnosti, ovaj je obrat posebno zaživio u tom polju istraživanja, doživljavajući refleksivnu sintezu u dvije sada već klasične studije, Lehmannovom Postdramskom kazalištu (2004) i McKenziejevom Izvedi ili snosi posljedice (2006). Na užem planu umjetničkog polja ta je transformacija artikulirana kao praktički obrat.

Kershaw (2011) ukazuje u kojoj mjeri epistemološka reevaluacija prakse u umjetničkom stvaranju — koju donosi praktički obrat - provocira dominantnu samorazumljivost unutar kartezijanske paradigme u kojoj je tjelesna spoznaja konstitutivno sekundarna. Kako ću nešto kasnije izložiti, na planu geste ta je provokacija naoko trivijalna, no potencijali destabilizacije akademskih protokola očito su percipirani. Kao posljedica toga, i na konceptualnom i na organizacijskom planu u posljednjih dvadesetak godina stasala je nova istraživačka orijenta- 
cija u polju izvedbene teorije koja se okvirno naziva obrazovni obrat. Zbog nepostojanja fundamentalnih tekstova te intenzivne dinamike koja otežava, a možda u ovom trenutku i onemogućuje, sintetski osvrt ili konsolidaciju lakatoševski pojmljenog istraživačkog programa, smatram da sâm termin obrata ovdje emfatički treba uzeti u proceduralnom smislu.

Ocrtom aktualne dinamike i trasiranjem genealogije nekih aktualnih nedorečenosti i idiosinkrazija izvedbene teorije u raspravi Rancièrea $i$ Althussera povodom događajâ iz 1968., pokušat ću naznačiti u kojoj je mjeri pri obrazovnom obratu moguće govoriti o iznevjerenju emancipatorskih potencijala koje je inaugurirao praktički obrat.

\section{Praksa kao polje znanja}

Iako se distinkcija teorije i prakse kao odijeljenih dimenzija znanja, unatoč svim antagonističnim interpretacijama, može locirati već kod Platona (FANTL, 2017), filozofsku konsolidaciju doživljava u Ryleovoj studiji The Concept of Mind (1951). Tu se s jasnom konceptualnom ambicijom uvode dva registra znanja - proceduralno znanje i deklarativno znanje, ili znanje kako i znanje da. Dok "znanje da" podrazumijeva poznavanje činjenica (da je nešto tako kako jest), "znanje kako” odnosi se na znanje kako izvesti određeni zadatak, kako nešto napraviti. Kao klasičan primjer može se uzeti distinkcija između poznavaoca kuharstva i kuhara. Dok prvi može raspolagati fascinantnom količinom činjenica i informacija o hrani, kuharskim tradicijama, metodama organizacije kuhanja i sl., to mu znanje neće biti dostatno za pripremanje jestivog jela. S druge strane, kuhar može biti apsolutno neupućen u bilo kakvu povijesnu, kulturnu ili biološku faktografiju oko svog zanata, a biti sposoban proizvesti izvrsno jelo. Već i na temelju ovakvog primjera, ova se razlika može prevesti u kolokvijalnu frazeologiju kao teorijsko i praktično znanje.

Teorije umjetnosti, pa tako i teorija izvedbenih umjetnosti, tradicionalno je nesklona uvidima i perspektivama koje potječu iz analitičke filozofske tradicije ${ }^{01}$ pa ne iznenađuje previše da Ryleova kategorizacija nije zaživjela u umjetničkoj refleksiji. No, kako sam već naznačio,

01 Najreprezentativniji pregled dominantnih teorijskih perspektiva $u$ polju studija izvedbe nude Reinelt i Roach u zborniku Critical Theory and Performance (prošireno izdanje 2007.). Izdanje nudi pregled devet najvažnijih teorijskih perspektiva i među njima nema ni spomena, a kamoli pregleda, bilo kojeg analitičko-filozofskog pristupa umjetnosti. 
praktički obrat se ipak desio, slijedeći doduše neke druge epistemološke parametre. I na ovoj točki dolazimo do značajne divergencije. Dok je analitička filozofija pružila problemu proceduralnog ili praktičkog znanja refleksivni dignitet u obliku širokog spektra polemika, ${ }^{02}$ u teoriji izvedbenih umjetnosti on se kretao poprilično drugačijom putanjom. U zborniku Research Methods in Theatre and Performance (UR. KERSHAW I NICHOLSON, 2011) jedno od devet poglavlja posvećeno je praktičkom istraživanju u umjetnosti. $U$ njemu Kershaw već na početku napominje:

"Ni teatrologija ni izvedbeni studiji ne mogu postojati bez kreativnih praksi izvođača, glumaca, redatelja, dizajnera (...) a ipak, odnosi između istraživačica i istraživača koje su stvorile disciplinu i ljudi iz prakse koji su stvarali umjetnost povijesno su uglavnom bili problematični." (2011: 63)

Snažna kartezijanska tradicija, tvrdi autor, vjerojatno je bila glavna prepreka ravnopravnoj legitimaciji tjelesnih umjetničkih praksi kao spoznajno vjerodostojnih protokola proizvodnje znanja i tek nastupom praktičkog obrata, negdje tijekom 1960-ih, situacija se postepeno preokreće. Glavne pravce konverzije Kershaw prepoznaje u pomaku sa strukture na aktivnosti, s fiksiranosti na procese, s reprezentacije na sâmo činjenje, s individualnosti na kolektivitet, čime se klasična epistemička relacija subjekta spram objekta značajno mijenja. Ili, riječima Theodora Schatzkog, u osvrtu na praktički obrat u društvenim znanostima: "[praktičke] koncepcije u snažnom su kontrastu s perspektivama koje privilegiraju pojedince, interakcije, jezik, označiteljske sisteme, svijet života, institucije ili uloge, strukture ili sisteme" (2005: 12) u razumijevanju socijalnog. Zajednička je potka obaju polja odustajanje od fiksiranosti individualnog subjekta kao instance spoznaje, ali i objekta kao značenjski omeđene cjeline koja je u toj zatvorenosti, barem u principu, potpuno spoznatljiva.

Od 1990-ih razni tipovi istraživanja, obilježeni spomenutom dinamikom, koji se provode samom umjetničkom praksom, a zaživjeli su pod imenima praksa-kao-istraživanje, izvedba-kao-istraživanje, praksom-vođeno-istraživanje, stječu akademski legitimitet. Kershaw nudi minimalnu operativnu definiciju koja obuhvaća te rodno bliske perspektive:

02 V. npr. spomenuti Fantlov pregled. 
"praksa-kao-istraživanje označava korištenje praktičkih, kreativnih procesa kao metoda (i metodologija) istraživanja sui generis, a koje su uobičajeno, iako ne i ekskluzivno, povezane sa sveučilištima i ostalim institucijama visokog obrazovanja." (2011: 64; istaknuo G.P.)

Zadnja specifikacija krucijalni je moment dijagnostike koju u ovom radu pokušavam iznijeti. Unatoč programatskom opredjeljenju za destabilizaciju ili čak dekonstrukciju uvriježene epistemološke relacije, tendencija ka akademskoj legitimaciji, pa i akreditaciji, ključan je faktor $u$ reteriranju praktičke orijentacije, ali i njezinom pripitomljavanju, adaptaciji u tradicionalne akademske modele proizvodnje znanja.

\section{Pravo na proizvodnju znanja}

U nedavnom osvrtu pod simptomatičnim naslovom "Don't Let Students Run the University” američki kultur-pesimistički autor Tom Nichols (2019) zdvaja nad činjenicom da se studenti usuđuju zahtijevati kome bi se na prostorima sveučilišta trebalo dozvoliti iznošenje stavova. Uslijed jačanja ekstremno desne retorike, zakrabuljene maskom slobode govora, u posljednjih nekoliko godina na američkim sveučilištima pojavljuje se sve snažniji i sve artikuliraniji otpor takvoj interpretaciji slobode govora. Kao i svi socijalni pokreti, ni ovaj nije lišen internih kontradikcija, što autorima poput Nicholsa daje dodatnu snagu u raspirivanju panike oko studentskih pretenzija. ${ }^{03}$ Međutim, Nicholsova gesta ni po čemu nije originalna ni nova. Štoviše, i sâm ukazuje na izvore ove "krize", naime dinamiku studentskih protestâ u 1960-ima i pronicljivo domeće kako studentski zahtjevi više nalikuju na uredbe iz perioda kineske Kulturne revolucije, a to je po prirodi stvari uvod u "totalitarizam".

Nicholsov prilog ne pretendira na analitičku rigoroznost $i$ više je vapaj za povratkom pravih vrijednosti nego domišljeni kritički osvrt na zamijećeni problem. Međutim, on revitalizira nikad u potpunosti zamrle teze koje su od konzervativnog akademskog establishmenta upravo tijekom 1960-ih uspostavljene kao mjera zdravog razuma. Izvorišnu intervenciju ove vrste predstavlja pismo Imre Lakatosa tadašnjem direktoru londonskog sveučilišta Lon-

03 U ironično naslovljenom članku "Against Students” (2015) Sara Ahmed izlaže kako je okrivljavanje studenata za eroziju standardâ u visokom obrazovanju najekonomičnija "kritička" gesta kojoj se često utječu upravo instance efektivne moći u visokom obrazovanju. 
don School of Economics (LSE), u kojem se već tada proslavljeni filozof matematike i znanosti ostrvljuje na studentske zahtjeve za sudjelovanjem u upravljanju fakultetom i svoju poziciju pravda pozivajući se na akademsku autonomiju koja ne smije biti narušena nikakvim presezanjima izvana. U samom pismu Lakatos ne nudi popis niti se referira na bilo kakav izvor koji bi taksativno označio subjekte koji nemaju legitimitet za uplitanje u sveučilišne poslove te time precizno isključio studente. On doduše napominje kako je određivanje akademske politike striktno u domeni znanstvenika i ponekog uglednijeg člana akademske zajednice, iz čega se implicitno, ali jasno, može zaključiti da za studente u procesima odlučivanja mjesta nema.

U “Izdvojenom mišljenju” Studentski je sindikat LSE-a izložio svoje zahtjeve prema upravi. S jedne strane traže participaciju u upravljanju fakultetom, s druge mogućnost osmišljavanja i vođenja vlastitih kurseva, kao i odlučivanje u odabiru profesorâ (navedeno prema LAKATOS, 1997: 248). Temeljna zamjerka koju Lakatos upućuje principijelno je nerazlikovanje između tih dvaju tipova zahtjeva. Prvi su legitimni i tiču se prava na kritiziranje uprave i saslušanje studentskih prijedloga u tom smislu. Drugi tip zahtjevâ obuhvaća pretenzije prema upravljanju fakultetom, sudjelovanjem u odabiru profesorâ, sukreiranjem silabusa i sl. (ibid.). Kako Lakatos pošteno dodaje: "vidljivo je i tužno kako takvi militanti nemaju nikakvog interesa za apolitične i konstruktivne studentske zahtjeve" (1997: 249). Elaboracija Lakatosevih argumenata nastavlja se u taksonomiji horror scenarija koji bi se mogli odviti ako uprava popusti zahtjevima drugog tipa. Iako su te paranoidne, klasično hladno-ratovske spekulacije zabavne, one ne doprinose suštinski temeljnom argumentu.

Ono što je međutim ključno, i što Lakatos u ovom iskazu iznosi na planu vjerojatno ne potpuno osviještene fraze, inzistiranje je na apolitičnosti koja bi bila jamac protiv ideoloških zastranjenja. Prema navedenoj opasci, koju argumentacijski okvir svakako snaži, apolitičnost je preduvjet konstruktivnosti, odnosno racionalne, neostrašćene deliberacije o problemu. Dok se kod eksplicitno konzervativnog kritičara poput Lakatosa ovakva pozicija može i očekivati, nešto je manje vjerojatno pronaći analognu distinkciju u jednoj od stožernih instanci ortodoksnog marksizma, naime u Althusserovom opusu. Unatoč neusporedivo ambicioznijoj i teorijski rafiniranijoj artikulaciji, Althusserovo depolitiziranje sustava proizvodnje znanja 
predmet je Rancièreove razorne kritike u članku "O teoriji ideologije (Althusserova politika)" iz $1969 .{ }^{04}$

Naime, u svome radu iz 1965., koji je ostao neobjavljen sve do prijevoda na engleski 1990., "Theory, Theoretical Practice and Theoretical Formation: Ideology and Ideological Struggle”, Althusser uspostavlja čvrstu konceptualnu distinkciju između znanosti i ideologije, i ona će do prijelomnog rada Idelogija i ideološki aparati države iz 197o. biti okosnica i teorijsko ishodište Althusserova razumijevanja proizvodnje i primjene znanja u kapitalističkom sustavu. Prema Althusseru, usuprot buržujskim disciplinama povijesti i filozofije, kao okviru razumijevanja čovjekova djelovanja u svijetu, Marx je u Kapitalu inaugurirao znanstveni pristup koji se programski dijeli na historijski materijalizam i dijalektički materijalizam. Historijski materijalizam je "znanost o načinima proizvodnje, njihovoj specifičnoj strukturi, konstituciji, funkcioniranju i oblicima tranzicije iz jednog načina $u$ drugi” (ALTHUSSER 1990: 7). S druge strane, dijalektički materijalizam ili filozofija marksizma pandan je buržujskoj teoriji spoznaje. No, za razliku od ahistorijskih koncepcija znanja svojstvenih potonjoj, dijalektički materijalizam je "teorija povijesti znanja, odnosno realnih uvjeta u kojima se odvija proces proizvodnje znanja (...)” (1990: 8). Da bismo uopće razumjeli što je prava znanost, "potrebno je znati kako se konstituira, kako se proizvodi” (1990: 14).

Već iz ovih uvodnih određenja razaznatljiva je temeljna ideja Althusserovog reza: inzistiranje na primatu prakse, odnosno praktičke proizvodnje znanja, usuprot vulgarnom empirizmu koji ostaje pri pukim datostima u spoznajnom činu. Ideologija je, nasuprot tome, ona domena proizvodnje značenja koja naturalizira razumijevanje svijeta kao zbira ahistorijskih datosti. U klasnim društvima, smatra Althusser, "ideologija je reprezentacija stvarnosti, ali nužno iskrivljena jer nužno pristrana i tendenciozna - tendenciozna jer joj cilj nije ljudima pružiti objektivno znanje o društvenom sustavu u kojem žive, nego, upravo suprotno, plasirati mistificirane reprezentacije o tom društvenom sistemu kako bi ih se zadržalo na svom mjestu u sustavu klasne eksploatacije" (1990: 29). Na temelju takve specifikacije, a u skladu s ranije rečenim, ideologija je onaj registar uvida u stvarnost koji ne osvjetljava proizvodnju, odnosno proceduralnu dinamičnost stvaranja i distribucije znanja, nego taj aspekt proizvedenosti zakriva.

04 Ovdje prema engleskom izdanju Rancière (1974), "On the theory of ideology (the politics of Althusser)". 
Politički zalog marksističke epistemologije bio bi, u parafrazi Marxovog obračuna s Hegelom, upravo u okretanju buržujske epistemologije naglavce, u otkrivanju onih dimenzija koje se tradicionalnim radom ideologije buržujskog društva smještaju onkraj povijesti (njegove proizvodnje). Historijski i dijalektički materijalizam jesu prakse "dekonstruiranja" takve navodne samorazumljivosti. Cilj buržujske ideologije, dodaje Althusser, osiguranje je društvene kohezije, odnosno stabilizacija klasnog društva kroz funkcionalističku reafirmaciju društvenih položajâ, odnosno prihvaćanja nužnosti statusa quo kao prirodne dispozicije društvenog sustava (1990: 28).

Upravo na ovoj točki Rancière utemeljuje svoju kritiku koja ima za cilj dokazati da Althusserovo neslaganje sa studentskim prosvjedima 1968. nije bila slučajna aberacija ili nedomišljena gesta, nego dosljedna aplikacija reakcionarne teorijske pozicije. Naime, konceptualiziranje ideologije kao sistemskog obilježja buržujskog društva, koja ima za cilj održavanje funkcioniranja tog sustava, durkheimovska je funkcionalistička gesta. Za razliku od toga, marksistička ontologija kapitalizma polazi od klasne borbe kao temeljnog ishodišta društvene dinamike pa time i temeljnog generatora znanja kao dijela te dinamike. Drugim riječima, ako se, slijedeći Marxov epistemološki rez, odmičemo od petrificiranih instanci buržujske epistemologije koja zapanjeno staje pred objektima svog istraživanja, dužni smo ideologiju sagledavati kao efekt klasne borbe, a ne kao svojstvo društvenog totaliteta koje postoji neovisno o borbi i u principu se može na isti način detektirati u robovlasničkom sustavu, feudalizmu ili čak i socijalizmu. Prema Rancièreu (1974: 4), Althusser to previđa i faktički uspostavlja dihotomiju između ideologije kao oružja vladajuće klase i znanosti kao oružja proletera, čime ponavlja matricu buržujske epistemologije koja operira na kontrapoziciji "znanosti i njezinog Drugog (mnijenja, greške, iluzije, itd.)".

Ova će se slijepa pjega, smatra Rancière, ponoviti i u Althusserovoj analizi sukoba između Komunističke partije Francuske (CPF) i Nacionalnog saveza francuskih studenata (UNEF). ${ }^{05}$ Dok su studenti zahtijevali "kvalitativno" propitivanje klasno-antagonistične relacije između poučavateljâ i onih koje se poučava, Althusser spušta prijepor na problem sadržajâ koji se predaju, čime eminentno klasnu problematiku "prevodi" u sraz istine i laži. Dakle, za razliku od revolucionarnih zahtjeva studenticâ i studenata, Althusser se kreće u okvirima

05 U tekstu "Problèmes étudiants", v. La Nouvelle critique, siječanj 1964. 
političkog revizionizma (analognog onome Komunističke partije), tretirajući istinu kao revolucionarno sredstvo, dok bi laž, odnosno ideologija, bila reakcionarno sredstvo.

Centralni problem takvog razumijevanja leži u aplikaciji marksističke teorije koja umjesto rastakanja temeljnih kategorija buržujske socijalne ontologije, faktički, u rukama Althussera postaje alat njezina osnaživanja. Kako naglašava Rancière, reakcionarnost buržujske organizacije univerziteta ne proizlazi iz toga što bi se na tehničkim ili medicinskim fakultetima iznosile laži, nego zbog "specifične strukture tih institucija, selekcijskih mehanizama, odnosa između studenata/ studentica i službenog osoblja, koje istovremeno posjeduje i znanje i povlašteno mjesto u socijalnoj hijerarhiji. Dominacija buržoazije i pripadne ideologije nije stoga izražena u sadržajima koji se predaju, nego u strukturi okoline u kojoj se prenose (...) Ideologija nije tek zbir diskursa ili sustav ideja, [ona je] moć organizirana u institucije" (1974: 6). Zato zadatak revolucionara nije zahtijevati više znanstvenosti što bi, prema naprijed izloženim iskazima, potpisao i jedan notorni konzervativac poput Lakatosa - nego iz marksističke pozicije tražiti rekonfiguraciju čitavog režima poučavanja. Ako je krajnji horizont "revolucionarnog" zahtjeva zamjena lažnog diskursa istinitim, jedini efekt je snaženje već postojećih relacija u obrazovnom polju koje su konstitutivno buržujske.

Slijedeći Athusserovu analitiku, osuđeni smo, prema Rancièreu, na previđanje činjenice da "univerziteti ne poučavaju 'znanost' u mitskoj čistoći njezine biti, nego selekciju znanstvenih znanja koji su artikulirani kao objekti znanja. Prijenos znanstvenih znanja ne proizlazi iz samog koncepta znanosti, nego sačinjava dio oblika aproprijacije znanstvenog znanja, a ti oblici su klasni oblici aproprijacije” (ibid.). Drugim riječima, "znanje institucionalno postoji samo kao instrument klasne vladavine”, što znači da je svaki poučavateljski odnos ujedno i instanca klasne borbe. Prema Althusseru, "funkcija poučavanja je prijenos određenog znanja subjektima koji to znanje nemaju. Poučavateljska situacija stoga počiva na apsolutnom preduvjetu nejednakosti između znanja i neznanja”. ${ }^{06}$ Dosljedno prethodnoj elaboraciji statusa znanja, i ovdje nedostaje sagledavanje poučavateljskog odnosa kao klasnog odnosa. Štoviše, ova precizna definicija može stajati u svakom udžbeniku i najkonzervativnije pedagogije. $\mathrm{Na}$ temelju ovih momenata Rancière zaključuje kako Althusserova

06 Navedeno prema Rancière, 1974: 7. 
teorija ideologije funkcionira kao teorija imaginarne klasne borbe od koje profitira realna klasna kolaboracija, odnosno na političkom planu, revizionizam (1974: 8).

U okviru ovakve dijagnostike možemo zaključiti kako revolucionarne pretenzije u polju visokog obrazovanja moraju u prvom redu raskrstiti s ishodišnom asimetrijom koja distribuciju moći u tom polju regulira po principu količine znanja koju dionici tog procesa posjeduju. Budući da se pretpostavlja da studentice/studenti nužno znaju manje od profesorica/profesora, strukturno je proizvodnja znanja dodijeljena profesorskom kadru. Osporavanje neupitnosti i samorazumljivosti tih relacija otvara prostor moguće emancipacije koja će nadilaziti nereflektirane opozicije istine i laži, znanja i neznanja kao parametara ili uloga u klasnoj borbi u polju visokog obrazovanja.

\section{Obrazovni obrat}

Prema Eszter Lázár (2011) obrazovni obrat "opisuje tendenciju u suvremenoj umjetnosti koja prevladava od druge polovice devedesetih godina, u kojoj su se različiti modusi obrazovnih formi i struktura, alternativne pedagoške metode i programi pojavili u kustoskim i umjetničkim praksama”. Naglasak pritom nije na umjetničkim objektima, nego "na samom procesu, kao i korištenju diskurzivnih, pedagoških metoda i situacija, unutar i izvan izložaba”. Stvaranje unutar ovog okvira uključuje "razvijanje novih metodologija koje omogućuju demokratizaciju pristupa znanju, korištenje novih žanrova i metoda izlaganja, kao i transformaciju položaja umjetnice, kustosice i gledateljice, kao i formativni angažman sudionika u projektu" (istaknuo G.P.). Budući da se radi o preglednom, leksikonskom članku, autorica ne zalazi u detaljniju elaboraciju izloženih aspekata već se zadovoljava taksativnim navođenjem mahom formalnih obilježja nove orijentacije.

Teorijski elaboriraniju razradu koncepta u svojoj studiji posvećenoj izvedbenom predavanju nudi izvedbena umjetnica i teoretičarka Jasna Jasna Žmak. Ona značajan dio argumentacije posvećuje genealogiji izvedbenog predavanja, a u njoj obrazovni obrat ima ključno mjesto. Iako je umjetnost od Horacija preko Schillera i Brechta naovamo gajila pretenzije ka poučavanju, u svim tim slučajevima riječ je o "moralnom ili građanskom odgoju (...) a ne o razumijevanju umjetnosti kao mjesta koje u svoje reprezentacijske modele uključuje formate inače pripadajuće obrazovnom sustavu" (ŽMAK 2018: 27-28). Dok je u prethodnim slučajevima naglasak bio prvenstveno na učincima kod publike, "za obrazovni obrat karakteristična je upravo konkret- 
na aproprijacija obrazovnih modela — predavanja, škole, laboratorija, istraživanja, akademije, diskusije, simpozija, konferencije - i njihova rekontekstualizacija unutar umjetničkog diskursa i to s ciljem njihovog radikalnog preoblikovanja s obzirom na izmještanje iz obrazovnog u umjetničko polje” (ibid.). Žmak naglašava kako "obrazovni obrat očito nije pojava koja je izolirana od ostalih društvenih procesa te $u$ tom smislu specifična samo za umjetničko područje, već je dio šireg obrasca koji je simptomatičan za sve sfere ljudskog društva, pa tako i za onu umjetničku” (2018: 31).

Slično primjećuje i Irit Rogoff, kustosica i istraživačica u polju vizualne kulture, koja je u diskursu kustoskih praksi prva počela koristiti sintagmu "obrazovni obrat" (educational turn). Rogoff svoj, danas već antologijski, tekst "Turning” (2008) otvara problematiziranjem tada već rastuće tendencije ka obrazovnom obratu. Pita se je li riječ o "strategiji čitanja ili interpretativnom modelu”, primjeni jedne dimenzije znanja (pedagogije) na drugu (kustoske prakse), ili je pak riječ o pokretu koji otvara neke nove horizonte, "ostavljajući pritom iza sebe prakse iz kojih je taj pokret proizašao”. Unatoč ogromnoj proliferaciji pojmova koji označavaju nove prakse, poput "proizvodnje znanja”, "istraživanja”, "otvorene proizvodnje”, "samoorganizirane pedagogije”, Rogoff primjećuje nezanemarivu bliskost s ekonomijama znanja, u smislu da svi ti pojmovi predstavljaju segment liberalizacije koja prožima svijet suvremene umjetnosti. ${ }^{07}$ Projekt Academy u kojem je sudjelovala, pokušao je, usuprot tehnokratskim naputcima Bolonjske reforme, razviti svojevrsnu protutežu novim politikama — profesionalizaciji, birokratizaciji, privatizaciji, ali i sve većem stupnju nadzora te kulturi mjerljivih ishoda koje dominiraju europskim visokim obrazovanjem - i suprotstaviti tim tendencijama obrazovanje kao potencijalni model alternativnih artikulacija akutnih društvenih pitanja. Sami pokušaji takvih akcija bili su, tvrdi autorica, "niskog profila, ne-herojski i nipošto ne razveseljavajući, teški za bilo kakvu kategorizaciju, ali ipak izuzetno kreativni”.

Unatoč ovim “nedostacima”, posezanje za obrazovnim poljem kao prostorom iznalaženja eksperimentalnih modela organizacije društve-

07 Postfordističke interpretacije "novih" ekonomija uvjerljivo je, empirijski i konceptualno, demontirala, među ostalima, Ursula Huws (2003, 2014), naglašavajući krutu materijalnu realnost koja omogućuje našu "virtualnu" eru. Za ovaj rad ta argumentacija nije presudna, ali je važan naglasak na ambivalentnosti tobožnje fleksibilizacije, koja dolazi uz liberalizaciju polja. 
nosti, u kojima je promašaj dopušten, a kontrola efikasnosti značajno manja nego u drugim domenama društvene reprodukcije, naznačuje u najmanju ruku prepoznavanje bar principijelne otvorenosti tog polja, koju empirijska aktualnost postojano dokida. Rogoff doduše naglašava taktički moment odabira obrazovnog polja, budući da je u njemu bilo najviše inicijativa i grupa koje su u očajanju nad propozicijama Bolonjske reforme bile voljne djelovati u smjeru osporavanja nove politike. Iako su glasovi disenzusa postojali i u umjetničkom polju, koje joj je kao eminentnoj kustosici itekako poznato, strukturne preduvjete radi kojih bi obrazovno polje bilo privilegirana instanca revolucioniranja društvenih odnosa autorica ne dotiče. ${ }^{08}$ Stoga akcije nje i njezinih suradnika mogu djelovati više kao očajnički, slabo artikulirani krik pred žrvnjem tržišne logike, nego kao profilirana politička artikulacija trenutne situacije. Međutim, te strukturne determinante ističe Žmak i navodi:

"umjesto težnje za autonomijom umjetnosti, danas je za njezinu legitimaciju u javnom polju potrebno upotrijebiti radikalno drugačiji diskurs koji se referira upravo na njezinu sposobnost za proizvodnju znanja, a posrednik je u procesu legitimacije umjetnosti kao sposobne za to bio upravo obrazovni obrat (...) što je posljedično značilo nametanje imperativa svrhovitosti i učinkovitosti te prestanak legitimizacije znanja 'kroz metode kojima je generirano, već kroz efikasnost njegove uporabe kao resursa." (2018: 36)

\section{Rezime posrtanja}

Inicijalno odmicanje od konvencionalnih kazališnih poetika, pa potom i nastajanje novih tipova refleksije o tome, obilježilo je praktički obrat u njegovim začecima pred pedesetak godina. Emancipatorsko obećanje, koje su početne geste posjedovale, izvjetrilo je s razvojem, iscrpilo se u nizanju formalnih eksperimenata, kako u polju umjetničke prakse tako i teorije o njoj. Obrazovni obrat, kao zadnja postaja na toj putanji, stasao je (i) na zahtjevima za demokratizacijom pristupa umjetničkom obrazovanju te transformacijom statusa uključenih dionika. Iako s očitim političkim ulogom koji u samoj stilskoj formulaciji nije pretjerano zvati radikalnim, obrazovni je obrat na kraju pao žrtvom

08 Zbornik Are You Working Too Much? Postfordism, Precarity, and the Labor of Art (ur. Aranda, J., Wood, B. K., Vidokle, A.) iz 2011. sastoji se od priloga autorica i autora koji su već godinama upozoravali na analogne procese u polju umjetnosti. 
konformiranja s birokratskim zahtjevima svrhovitosti, učinkovitosti $\mathrm{i}$ isplativosti. Drugim riječima, strogo hijerarhizirani sustav visokog obrazovanja bez većih je teškoća aproprirao i najradikalnije zahtjeve obrazovnog obrata, bez doglednih izgleda da se uruši pod njihovom težinom.

Nad time možemo zdvajati, a razloge tome možemo pronaći u levijatanskoj snazi suvremenog kapitalizma, neusklađenosti i nekoordiniranosti reformskih zahtjevâ s raznih instanci, nedostatku efektivne moći, i vjerojatno svi ti razlozi u nekoj mjeri zaista jesu doprinijeli aktualnoj situaciji. S druge strane, možemo razmotriti u kojoj je mjeri suštinska apolitičnost izvornog zahtjeva unaprijed osudila cijeli projekt na ovakav ishod. Na tragu Rancièrea, ako borbu za moć u visokom obrazovanju uokvirimo parametrima količine (istinitog) znanja, pa kao politički zadatak postavimo dostizanje te iz početka asimetrično razdijeljene količine, najznačajniji efekt koji možemo postići je priznavanje naše kompetencije od strane ovlaštenih mandarina akademskog sustava — naime, priznanje da smo osposobljeni proizvoditi istinu u okviru protokolâ koje sami nismo osmislili. Time se međutim ne zahvaća centralno pitanje: na koji način znanstveni i visokoobrazovni sustavi u njihovom aktualnom formatu sudjeluju u generiranju klasnog antagonizma $i$, posljedično, klasne aproprijacije proizvodnje znanja. Odgovor na to pitanje ne mogu nam dati ni najkreativniji zamišljaji, oblikovani najmaštovitijim stilizacijama. Odgovor jedino može proisteći iz klasne borbe na terenu.

\section{LITERATURA}

Ahmed, S. (2015). Against Students. URL: https://thenewinquiry.com/against-students/ (očitano 20. 9. 2018.)

Althusser, L. (1990). "Theory, Theoretical Practice and Theoretical Formation: Ideology and Ideological Struggle". U: Philosophy and the Spontaneous Philosophy of the Scientists. London, New York: Verso.

Aranda, J., Wood, B. K., Vidokle, A. (ur.) (2011). Are you working too much? Post-Fordism, Precarity, and the Labor of Art. Berlin: Sternberg Press.

Fantl, J. (2017). Knowledge How. The Stanford Encyclopedia of Philosophy (Fall 2017 Edition), Edward N. Zalta (ed.), URL: https://plato.stanford.edu/archives/ fall2017/entries/knowledge-how/

Fischer-Lichte, E. (2013). "Policies of Spatial Appropriation". U: Fischer-Lichte, E., Wihstutz, B. (ur.), Performance and the Politics of Space. London and New York: Routledge. 
Huws, U. (2014). Labor in the Global Digital Economy. New York: Monthly Review Press.

Huws, U. (2003). The Making of a Cyberteriat. Virtual Work in Real World. New York: Monthly Review Press.

Kershaw, B., Nicholson, H. (ur.) (2011). Research Methods in Theatre and Performance. Edinburgh: Edinburgh University Press.

Lakatos, I. (1997). "A letter to the Director of the London School of Economics". $\mathrm{U}$ : Mathematics, science, and epistemology. Cambridge: Cambridge University Press.

Lázár, E. (2011). Educational turn. URL: http://tranzit.org/curatorialdictionary/ index.php/dictionary/educational-turn/ (očitano 20. 9. 2018.)

Lehmann, H-T. (2004). Postdramsko kazalište. Zagreb, Beograd: CDU, Tkh.

McKenzie, J. (2006). Izvedi ili snosi posljedice. Zagreb, Beograd: CDU.

Nichols, T. (2019). “Don't Let Students Run the University”. URL: https://www. theatlantic.com/ideas/archive/2019/o5/camille-paglia-protests-represent-dangerous-trend//588859/ (očitano 15. 5. 2019)

Rancière, J. (1974). “On the theory of ideology (the politics of Althusser)”. Radical Philosophy, 7: 2-15.

Reinelt, J., Roach, J. (2007). Preface to the Second Edition. In Reinelt, J., Roach, J. (eds.) Critical Theory and Performance. Ann Arbor: University of Michigan Press.

Rogoff, I. (2008). Turning. URL: https:/www.e-flux.com/journal/oo/68470/ turning/\#_edn1 (očitano 20.9. 2018)

Ryle, G. (1951). The Concept of Mind. London: Hutchison's University Library.

Schatzki, T. (2005). Introduction: Practice theory. U: Schatzki, T., Knorr Cetina, K. and Eike von Savigny (ur.), The Practice Turn in Contemporary Theory. London, New York: Routledge.

Žmak, J. (2018). Izvedbeno predavanje kao žanr. Doktorska disertacija. Filozofski Fakultet u Zagrebu. 